\title{
The EU as an Anchor for Turkey's Macroeconomic and Trade Policy
}

\section{Mehmet Sait Akman and Semih Emre Çekin}

\subsection{INTRODUCTION}

Relations with the European Union (EU) have served as a benchmark for Turkey's domestic policy orientation and as an incentive for reforms for several decades. In this context, Turkey's economy is no exception, although its transformation from an import-substituting economy to an open and globally integrated economy had its ups and downs. While the process required domestic policy reforms with strong commitments from policymakers, implementing optimal policies was difficult and often necessitated the approval of a strong external actor in order to confirm the credibility of Turkey's policy commitments. As Öniş and Şenses (2009: 305-306) state, it was a combination of external and domestic factors that

\footnotetext{
M. S. Akman ( $\square)$

Economic Policy Research Foundation of Turkey (TEPAV), Ankara, Turkey e-mail: sait.akman@tepav.org.tr

S. E. Çekin

Department of Economics, Turkish-German University (TDU), Istanbul, Turkey

e-mail: scekin@tau.edu.tr

(C) The Author(s) 2021

W. Reiners and E. Turhan (eds.), EU-Turkey Relations, https://doi.org/10.1007/978-3-030-70890-0_12
} 
contributed to the development of the Turkish economy; and a comprehensive analysis of the Turkish economy cannot be fully complete without examining the influence of external actors in shaping economic policies.

The influence of the EU on Turkey's domestic transformation has been subject to analysis from different perspectives. Tocci (2005) provides an analytical distinction for the EU's role, asking whether Turkey's accession process has been an external force triggering reforms and driving internal change, or whether domestic change has been spearheaded by domestic actors who used an external EU 'anchor' or were strengthened by it. Though a clear distinction is subtle and difficult to make, there are studies that focus on Turkey's anchor to the EU as a means to implement domestic transformations. Keyman and Öniş (2004) proposed that without a strong EU anchor it would be inconceivable for Turkey to transform itself into a more democratic and economically stable entity. In an earlier study, Uğur (1999) argued that in the absence of an EU anchor Turkish authorities' attempts at reforms and stabilization would remain largely non-credible, leading to an 'anchor-credibility dilemma'. In this context, anchoring can be defined as an attachment to an external entity that provides stability and confidence in an otherwise uncertain situation. Serving as a credible anchor, the EU would be expected to help solve 'time-inconsistency' ${ }^{1}$ problems stemming from domestic inefficiencies. It could do so by providing a transparent contract that would guide Turkey toward convergence with EU standards, and incentives for achieving these standards (see Uğur, 2003: 165; Öniş \& Bakır, 2007: 148 for a detailed explanation of the argument).

Turkey always relied on a strong external anchor to put constraints on policymakers. In the economic policy field this role was, for decades, mostly attributed to Bretton Woods institutions. In particular, International Monetary Fund (IMF) conditionality provided an impetus to Turkey's quest for stability and macroeconomic balancing for a long time, before the EU also assumed this role. From the start, Turkey's quest to join the EU was partly an integration initiative that necessitated strong

${ }^{1}$ Time inconsistency problems arise when the government's original decision on when to implement a certain policy reform (such as domestic reform or tariff liberalization) is no longer optimal at the specified time for implementation. A reason for this inconsistency can be, for instance, domestic inefficiency: the sector is not prepared for the reform and is therefore unable to successfully operate under the new circumstances. This creates a credibility problem for the government. External anchors like the EU may help the government make better-predicated policy commitments. 
convergence in economic policies. The accession process entailed meeting the Copenhagen economic criteria, which oblige candidates to acquire a functioning market economy, the capacity to cope with competitive pressures and harmonization with the acquis. In this context, the EU's role gained acceptance in Turkey for practical reasons, such as economic benefits and financial assistance, rather than for being a pivotal external anchor constraining Turkish policymakers' choices in the macroeconomic policy field.

This chapter examines the role of the EU in conjunction with other external actors in facilitating economic reforms in Turkey, concentrating on the macroeconomic effects of the EU and the effect on trade liberalization. In our analysis, we also discuss the volatility of the EU anchor. We find that in the macroeconomic policy field, the EU became a significant actor in Turkey's economic reform after the Helsinki Summit in 1999, when Turkey was granted the status of an EU accession candidate (see also Turhan \& Reiners, Chapter 1), and until around the global financial crisis of 2008, when many structural reforms were implemented that were mostly aimed at privatization, monetary policy, and public finance management. The EU anchor significantly deteriorated after 2008 when the reform process began to lag, the economies of Turkey and the EU faced significant turbulence after the global economic crisis, and bilateral political relations worsened.

Particular attention is paid to the establishment of the Customs Union (CU) between Turkey and the EU in 1995. It was a milestone in Turkey's trade policy; it substantially added to the liberalization process started in the early 1980s, and thereby complemented Turkey's multilateral commitments to the World Trade Organization (WTO). Since its establishment, the $\mathrm{CU}$ has been a ruling mechanism that has helped Turkey preserve its integration with European and global markets. However, the attractiveness of the $\mathrm{CU}$, if not its exigency, started to dissipate during the most recent decade largely because of the EU's growing number of preferential trade agreements with third parties. These were regarded by the Turkish political elite as the cause of asymmetries between Turkey and the global markets. We argue that the failure of the EU and Turkey to modernize the $\mathrm{CU}$ amid growing bilateral tensions endangers the EU's anchor role and undermines the strengthening of the trade partnership between the EU and Turkey, which remains one of the few well-functioning legs of the volatile bilateral dialogue between the two sides. 
The chapter is structured in two main parts. In the first part, it examines Turkey's macroeconomic reform process in the context of the EU's role as an anchor in three periods: from the 1980s to the Helsinki Summit in 1999, during the post-Helsinki accession process until 2007, and from the global financial crisis until the most recent developments. The second part analyzes the EU's anchor role for Turkey in trade policy, and in particular in the framework of the CU. The analysis is again structured in three periods, covering the years from 1996 to 2007, from 2008 to 2016 , and since then. The chapter closes with concluding remarks on the 'double anchoring' of Turkey to the EU and international institutions, and the implications of the absence of a clear EU membership perspective for Turkey's macroeconomic reforms and trade policy.

\subsection{The EU and Turkey's Macroeconomic Reform Process: An Effective ANChor?}

\subsubsection{From the 1980s to the Helsinki Summit}

In 1987, Turkey's Prime Minister Turgut Özal pushed for Turkey’s membership of the European Economic Community (EEC), with the aim of establishing an external anchor for the process of implementing an outward-oriented growth strategy. Özal envisioned that membership of the EEC would enable Turkey to further implement liberal policies and, more importantly, draw financial assistance in the form of foreign direct investment (FDI) and commercial credits from European countries (Öniş, 2004). At the end of 1989, the European Commission (EC) indicated Turkey's eligibility for membership but clarified that full membership was not feasible for the time being, given Turkey's size and level of economic development (European Commission, 1989). Instead, the Commission focused on the need to establish a CU in 1995 and deferred discussion of the issue of enlargement until a later date. While the EU's decision did not fulfill Turkey's expectations, this may be due to the fact that at the time the EU had not yet constructed a European model for its neighboring countries to pursue economic (and democratic) reforms; Turkey did not therefore receive EU guidance with respect to economic policy management.

In the 1990s, Turkey's economy was subject to several domestic and external challenges, such as the effects of the first Iraq War (1990-1991) and weak macroeconomic fundamentals. In this period, the establishment 
of the CU in late 1995 constituted the most significant step in EU-Turkey relations until the Helsinki decision of 1999. However, the positive atmosphere that formed around the CU quickly deteriorated when the European Council did not include Turkey in the list of the accession countries in the Luxembourg Summit in 1997. The EU's decision was largely based on Turkey's domestic deficiencies, inter alia, emanating from pressures on public finances (see Fig. 12.1), high inflation, and inconsistent monetary policy. Following the Cardiff European Council in June 1998, the Commission started to assess, in its regular country reports, Turkey's economy in light of the Maastricht criteria.

Turkey's candidate status was recognized by the Helsinki European Council in 1999. Öniş (2003: 9) considers it a 'fundamental turning point', as the candidate status incentivized Turkey to undertake reforms, including those in the economic sphere, and to conform to EU norms. The CU-despite its subsequent positive impact—did not have a similar transformative role in the Turkish economy in its early years.

\section{Public Debt and PSBR as \% of GDP}

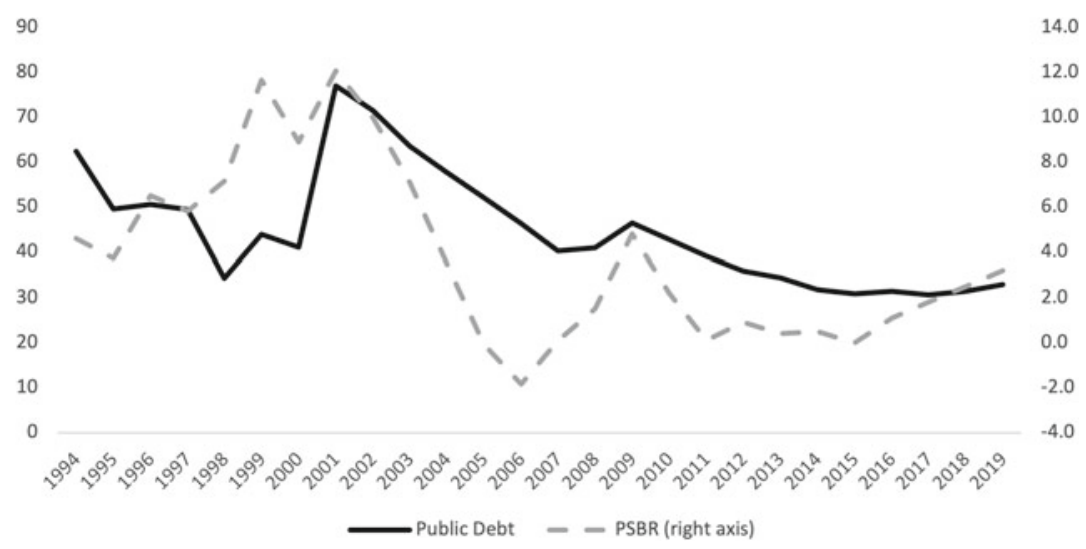

Fig. 12.1 Fiscal policy fundamentals: Turkey's public debt and public sector borrowing requirement (PSBR) as \% of gross domestic product (GDP) (Source Republic of Turkey Ministry of Treasury and Finance [2020]) 


\subsubsection{Post-Helsinki Process: Rising Hope for EU Membership on the Eve of Accession Negotiations}

The Helsinki decision of 1999 promoted the EU's role as an anchor for macroeconomic policymaking in Turkey. However, despite its political significance, the effect on the economy was not initially visible, and the IMF anchor that called for privatization and regulation of the banking system proved ineffective due to weak political commitments. Amid this fragile environment, Turkey experienced two consecutive crises-in 1999 and early 2001 - that severely affected its banking system (Togan \& Ersel, 2005; Öniş \& Bakır, 2007).

Following the crisis in February 2001, Turkey introduced the so-called 'Strong Economy Program' in order to balance the budget, increase competitiveness, and restore confidence in the market. Here, the influence of Kemal Derviş, who worked closely with the IMF and the World Bank as the Minister of Economic Affairs, was instrumental. The focus of the program was to restructure the banking system and to discipline public finances in order to achieve macroeconomic stability.

Along with fiscal discipline, the conduct of monetary policy was amended in the Central Bank Law-policy independence most importantly-and became an important element of Turkey's accession strategy. Stability in financial markets was addressed with the Capital Market Law and through the expansion of the role of capital market institutions such as the Banking Regulation and Supervision Agency and the Saving Deposit Insurance Fund (Pazarbaşıoglu, 2005; Hoekman \& Togan, 2005). These reforms and institutional restructuring were crucial in lowering inflation rates to single digits by 2004 .

While Bretton Woods institutions were pivotal in the formulation and implementation of these measures, the EU anchor also played a key role in avoiding time-inconsistency problems and raising certainty in the markets. In its first Accession Partnership Document in March 2001, the EU suggested the implementation of reforms in financial sectors and monetary policy, and measures addressed by the IMF/World Bank (Council of the EU, 2001). Following the guidelines in the document, Turkey prepared a lengthy 'National Programme for the Adoption of the Acquis', outlining the steps that would be taken to ensure convergence with Copenhagen and Maastricht criteria. As Öniş and Bakır (2007: 155) 
put forth following the 2001 crisis, the EU and IMF played a significant role as 'double anchors' in the process of reform and state-capacity development by enacting conditional agreements.

Seemingly satisfied with the speed and depth of Turkey's reforms, in 2004 the Commission made a recommendation to begin accession negotiations with Turkey in October 2005. This process helped the Turkish economy attract increasing amounts of FDI from EU member states. FDI inflow volumes remained very high until the effects of the global financial crisis hit advanced economies in 2008 (see Fig. 12.2). Increasing FDI flows not only serve to stabilize the financing of the current account, as opposed to portfolio investments that are short-term in nature, but also help companies achieve sophistication and complexity in production (Javorcik et al., 2017). In this way, Turkey achieved its target for primary surplus.

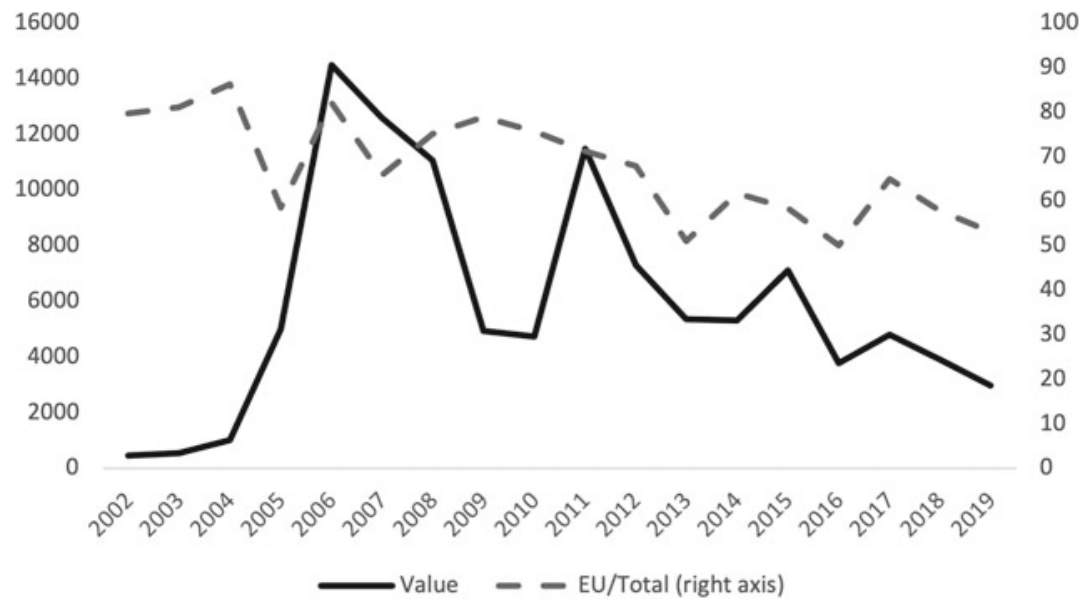

Fig. 12.2 Value and share of foreign direct investments (FDIs) in Turkey originating from the EU (2002-2019) (in million USD and \%) (Source Central Bank of the Republic of Turkey, Balance of Payments Directorate, Foreign Direct Investments in Turkey [2019]) 


\subsubsection{Backsliding in the Turkish Economy, Changing Macroeconomic Preferences, and the Weakening of the EU Anchor}

Following the onset of the global financial crisis and the resulting sovereign debt crisis of the euro area, significant domestic and external changes adversely affected Turkey's economy. On the domestic front, Acemoğlu and Üçer (2015) argue that the quality of Turkey's economic growth deteriorated around 2007 due to a change in the nature of the economic institutions and policies that had previously served to implement growth-enhancing reforms. They underline that the deterioration of relations with the EU was followed by a reversal in Turkey's economic development trajectory, which led to changes in the domestic political dynamics in Turkey. Accordingly, 'the EU's anchor for Turkish institutional reforms and leverage over Turkish politicians came to an abrupt end at around 2010 as the accession process almost completely stalled' (Acemoğlu \& Üçer, 2015: 23).

As regards external developments, Turkey's economic reform process was further disrupted by the 2008 financial crisis - a crisis of global scale that primarily started in the US subprime mortgage market and spread to other advanced and emerging economies through financial linkages. The crisis caused major disruptions in European financial markets, culminating in recessions in the euro area and contributing to the subsequent sovereign debt crisis (known as 'eurozone crisis') (Lane, 2012).

Throughout this period, the structural and economic reforms implemented during the early years of the AKP governments, assisted by the IMF and World Bank, were reversed as a result of the changes in Turkey's economic and political institutions. Öniş (2019: 5) argues that in the post-2011 era in particular, when shifts in global economic and political balances between advanced and emerging economies with the rise of blocks such as BRICS posed an alternative to Western economies and institutions, the AKP government preferred to embark on an 'alternative path of developmentalism'. These new avenues of economic expansion rendered Turkey less dependent on its traditional Western allies, including the EU, the IMF, and the World Bank. Hence, Turkey's reversal of its external economic conditions and worsening political relations with the EU triggered processes of 'de-Europeanization' (see also Alpan, Chapter 5), whereas relations with Russia, China, and Qatar became more relevant. 
In 2013, developments in Turkey and corruption charges against several ministers led to elevated risks for Turkey's finances. In its 2014 progress report, the EC encouraged Turkey to address these economic vulnerabilities by implementing long-term structural reforms and adopting an appropriate monetary/fiscal policy mix with the aim of lowering inflation rates and enhancing domestic savings (European Commission, 2014). Moreover, the eurozone crisis had started to influence Turkey's reform process, slowing down the EU's widening process and making the EU less appealing as an anchor of stability for third countries (Panagiotou, 2013; O'Brennan, 2013). While global credit conditions worsened for emerging economies such as Turkey during this period, a failed coup attempt in 2016 and the subsequent reaction of the government, which used emergency laws to allegedly contravene fundamental human rights, drew significant criticism from the EU. In its 2016 report, the Commission criticized Turkish authorities, saying that the reaction to the coup worsened the business climate and warned against a backsliding of economic reforms (European Commission, 2016a).

The post-2016 period also affected the volume of FDI outflows and the share of EU member states in FDI flows to Turkey. The decrease in FDI flows of the EU to Turkey had already kicked off after the global financial crisis (see Fig. 12.2). This trend became more pronounced with the political strain that ensued following the failed coup attempt in 2016. In 2016, the share of EU member states in FDI flows to Turkey decreased to the lowest level $(50 \%)$ since 2002 , and in 2019 the volume of annual EU FDI outflow to Turkey decreased to the lowest level since accession negotiations began in 2005. Strained relations with EU member states, as well as several terrorist attacks between 2015 and 2017, led to a significant drop in tourists from Europe, with implications for the large Turkish tourism economy. As travel statistics reveal, the number of German tourists, who traditionally comprise the largest group of foreign visitors to Turkey, decreased from 5.5 million in 2015 to 3.5 million in 2017, a pattern that was similar for other EU member states (Republic of Turkey Ministry of Culture and Tourism, 2020). In 2018, Turkey also experienced a serious currency crisis, which saw the Turkish Lira take a significant plunge, inflation rates above $20 \%$, and rising unemployment.

In its 2019 report, the Commission noted the serious backsliding in Turkey's fulfillment of the economic criteria and that the suggestions of the previous year-such as reducing imbalances by promoting domestic savings rather than relying on short-term portfolio inflows and improving 
the business conditions by means of strengthened rule of law and the judiciary (European Commission, 2018)—were not implemented (European Commission, 2019a). Despite the Turkish authorities' insistence that Turkey's membership of the EU remains an important goal, the EU's anchor role has diminished as developments on both sides precluded the reinstatement of a sustainable relationship.

The launch of a High Level Economic Dialogue (HLED) in 2016 following a call from European Council in December 2014, with the hope that this would support the continuation of economic dialogue between EU and Turkey and foster alignment of Turkey with the acquis (Council of the EU, 2014), has been a positive step in this period. However, HLED was no substitute for the smooth operation of the accession process, and could not provide a similar anchor. The economic dialogue between EU and Turkey can be understood as signaling the integration of Turkey into EU markets without the prospect of an eventual EU membership (Müftüler-Baç, 2017).

All in all, the EU's role as an anchor for macroeconomic transformation was particularly strong after Turkey was accepted as a candidate country in 1999. The EU was a strong driver of the reform process in conjunction with the IMF assistance that was initiated after the 2001 crisis and one of the main sources of FDI flows until 2008. These developments were closely linked with Turkey's membership aspirations to join the EU, especially following the Commission's advice to start accession negotiations. While the EU played a strong role until 2008 and remains the major economic partner of Turkey, its gravitational pull in the evolution of the Turkish economy decreased following the eurozone crisis. Subsequently, the end of Turkey's IMF standby arrangement in 2013, and the AKP government's resistance to its renewal, removed the IMF from its position as an anchor. In addition, political unrest, strained political relations with the EU, and heightened risk levels for investors weakened the EU's anchor role. These developments turned Turkey into a less appealing investment destination. Worsening economic conditions and a changing economic paradigm in Turkey started to worry domestic actors as well. Business associations such as the Turkish Industry and Business Association (TÜSİAD) asked for the reinvigoration of relations with the EU and to upgrade the CU in order to increase foreign investment and to motivate economic reforms. The statement by TÜSİAD's president, Simone Kaslowski, documents this understanding: 
We need progress in our relations with the EU our main economic partner. [...] EU membership perspective is the strongest element to raise confidence in our country and the interest of investors in a sustainable way. An assessment of the Customs Union reveals that upgrading tremendously affects both sides' economies and strengthens full membership perspective. (TÜSIAD, 2019, translated from Turkish)

\subsection{Trade Policy: The EU as an External (but Fading) Catalyst}

Trade is arguably the most advanced EU-Turkey policy area. Strengthening relations with the EU has been a major driving force of Turkey's trade policy for decades. Since the entry into force of the CU on 31 December 1995, the EU has been the main catalyst shaping Turkey's trade policy. While Turkey implemented its major trade liberalization steps long before joining the $\mathrm{CU}$, the EU anchor through the $\mathrm{CU}$ arrangement deeply affected Turkey's formulation, administration, and coordination of its trade and FDI policies.

In the early 1980s, before the launch of the CU, Turkey decided to replace its traditional import-substitution policy with the progressive liberalization of trade, foreign exchange, and investment regimes. Policymakers decided to implement an export-oriented industrialization strategy largely within the context of the paradigm shift in global economic policy of the time. Accordingly, they started to reshape Turkey's trade policy by striving for export promotion, facilitation of import licensing procedures, and liberalization of capital movements. However, the gradual transformation was repeatedly interrupted due to domestic resistance. Domestic actors did not believe that liberalization measures would actually be implemented, nor did they expect retaliatory tariffs from major trading partners such as the EU. This was a typical time-inconsistency problem, which convinced the domestic manufacturing industry not to support any restructuring and adjustments in order to sustain international competition, because tariff reduction commitments of the government were not credible.

During the 1980s and first half of the 1990s, the effect of the EU as an anchor on Turkey's trade policy was not significant, and trade reforms were mostly attributable to the IMF's policy conditionality and the World Bank's structural adjustment programs. The Bretton Woods institutions were externally motivating liberalization of Turkey's economic and trade 
policy. In the 1990s, under the domestic political and economic circumstances of that era, and without a prospective EU membership, Turkey began to deviate from the IMF and World Bank anchors. Policies did not effectively address the problems of fiscal deficits and inflationary pressures under short-lived coalition governments (Pamuk, 2012: 276-277). The decision to complete the $\mathrm{CU}$ with the $\mathrm{EU}$ in the mid-1990s was a turning point in stabilizing reforms and providing credibility and coherence for long-term liberalization measures.

\subsubsection{Credible Commitments Under EU Anchoring: Trade Policy and the Customs Union}

The entry into force of the CU was expected to place a constraint on the misallocation of domestic resources, and to lock in structural reforms to Turkish industry. The CU (EC-Turkey Association Council, 1996) required Turkey not only to eliminate customs duties on imports from the EU but to harmonize its policies with that of the EU in customs administration, technical standards, preferential trade scheme, intellectual property rights, competition policy, and state aids. Prior to the CU, Turkey's import regime was complicated by several red-tape procedures; it did not have a qualitative infrastructure for eliminating technical barriers to trade and did not have an effective competition law. However, the scope of the CU was confined to manufacturing and did not enable market access for services, agricultural products, and public procurement.

It can be observed that in the years following the establishment of the CU the EU started to become a strong anchor for Turkey's trade policy, avoiding the time-inconsistency problem by means of policy assurance. Beyond that, the mid-1990s also witnessed the establishment of the WTO, of which Turkey became a founding member. The new multilateral rulebook reflected the changing nature of global trade relations and brought extensive obligations for all parties. The EU had to adapt its own trade policy in line with the WTO agreements. While the CU ushered in a broader bilateral trade opening between the EU and Turkey, it also helped Turkey conduct its trade policy in accordance with multilateral rules. Corresponding to these developments, Turkey became committed to the path of trade liberalization and trade policy orientation via two significant external anchors: the 'bilateral track' with the EU under the guidance of the CU and the 'multilateral track' with WTO membership, 
the implementation of the latter being in close coordination with the former (Akman, 2012).

Amid this new environment, Turkey, in accordance with the CU, eliminated all customs duties, import quotas, and similar charges and measures with equivalent effects on industrial goods originating from the EU. It also committed itself to aligning its tariffs to third countries in line with the Common Customs Tariff (CCT) of the EU and to applying the EU preferential trade regime, in other words the conclusion of free trade agreements (FTAs) with third countries. The CU fostered a strong regulatory convergence between the EU and Turkey in customs modernization and trade facilitation based on an alignment process in anti-dumping and safeguard legislation, competition policy, customs practices, intellectual property rights, and technical standards (see for details Kabaalioğlu, 1998; Togan, 2012). To adhere to the CU requirements, Turkey also established several domestic regulatory agencies immediately before and after the establishment of the CU, including the Competition Authority, Turkish Patent Institute (currently Turkish Patent and Trademark Office), and Turkish Accreditation Agency. These developments show how the EU anchor transformed Turkey's trade policy with respect to policymaking and to the functioning of institutions in line with European standards (Balkır, 2016).

The benefits of the CU were hard to realize in its early years, for economic and political reasons. From an economic perspective, two factors need further elaboration. First, the CU initially did not boost exports to the EU-contrary to expectations-because the EU had already opened its markets to Turkish-manufactured products long before the entry into force of the CU. In practice, the CU actually opened Turkey's market to competition from European exporters. Second, trade liberalization alone is no guarantee of dynamic gains, an increase in the competitiveness of the manufacturing industry and boosting of FDI inflow, if it is not properly coupled with economic reforms.

Despite successful trade liberalization and regulatory upgrading in trade-related policies, the 1990s ended with economic difficulties. The stabilization program was adopted in $1999,{ }^{2}$ but it did not prevent Turkey from experiencing a deep balance of payments crisis in 2001, mainly

2 Turkey decided to start a stabilization program in 1999 with the support of the IMF. The program adopted was based on a pegged exchange regime under tight monetary policy and further liberalization of the economy. 
caused by the inefficient management of the public sector. This revealed that successful trade liberalization also required macroeconomic stability in order to help Turkey cope with competitive pressures (Kaminsky \& Ng, 2007). Thus, the CU's anchor role was confined mainly to trade policy issues and did not extend broadly into structural reforms for macroeconomic stability. The latter was provided instead by IMF conditionality and domestic policy choices in Turkey.

Politically, the CU was assumed to be not an end in itself but a major step toward full EU membership. However, it did not take too long to see that accession was a thorny road. The flaws in a weakly negotiated CU would be realized in the coming decades. Nevertheless, for its time the CU was a courageous decision that motivated Turkish business to demand policy changes and more far-reaching reforms, and to ask both the EU and the Turkish government to set a date for Turkey's EU integration and the opening of accession negotiations. The CU was a step toward solving the time-inconsistency problem through EU anchoring.

Overall, the CU had a positive impact on the Turkish economy in its first decade. Yilmaz (2011) argues that the opening of Turkish industries to international competition improved Turkey's allocation of domestic resources and allowed for dynamic gains through rising productivity and economies of scale in many sectors. Increased competition from the EU and other trade partners ${ }^{3}$ raised the total factor productivity in import-competing sectors such as automotive, consumer electronics, electrical machinery and equipment, and durable home appliances. The 'disciplining effect' of the CU helped these sectors upgrade their production process by moving up the technological ladder from lessskilled, labor-intensive products with lower technologies into mediumtechnology products with capital and skilled-labor intensiveness (Aysan \& Hacihasanoğlu, 2007; Akman, 2013). Accompanied by post-2001 crisis macroeconomic reforms, EU-Turkey bilateral trade increased dramatically (see Fig. 12.3) until the obvious decline that followed the 2008 global financial crisis.

This period can be characterized as one of coexistence and macroeconomic stability via a close cooperation with the IMF and the World Bank and the EU anchor via the CU (Öniş \& Bakır, 2007: 150). The political

\footnotetext{
${ }^{3}$ Lower tariffs under the CCT and free trade agreements with several neighbouring countries according to Article 16 of the decision on the $\mathrm{CU}$ also provided duty-free access for Turkey's trading partners.
} 


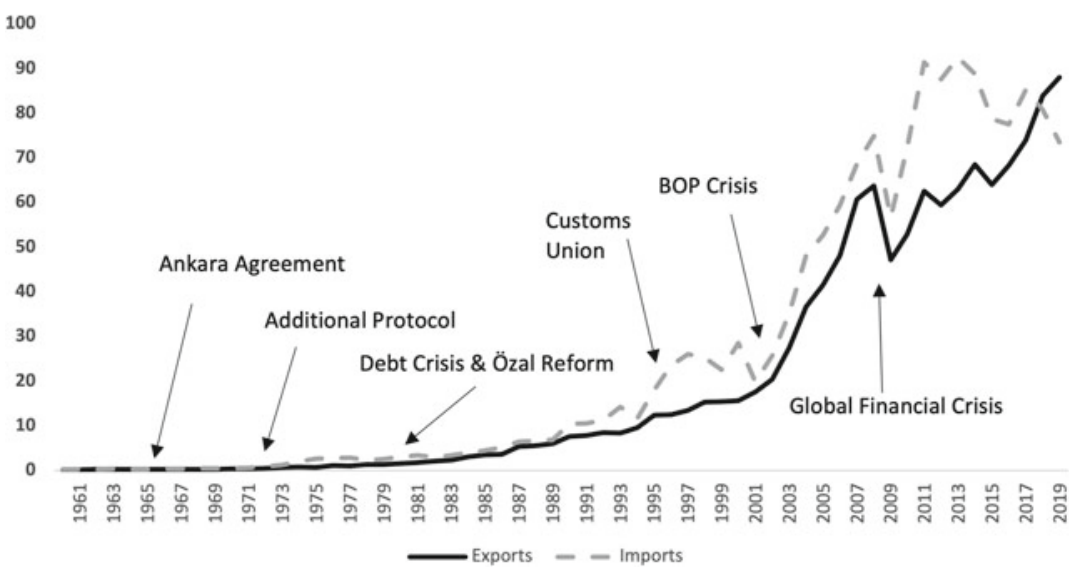

Fig. 12.3 Turkey's bilateral trade with the EU (1961-2019) (in billion USD) (Source International Monetary Fund [2020])

perspective for full membership also solidified the EU's anchor role when Turkey's EU accession negotiations commenced in October 2005.

\subsubsection{The Customs Union Under Changing Political and Global Circumstances}

The optimism that arose as a result of the launch of accession negotiations in 2005, and with it the EU's capacity to act as an influential anchor, began to dissipate in the post-2005 period (Icoz, 2016). The negotiations did not get off to a smooth start as the EU declared that Turkey's accession was an 'open-ended process, the outcome of which cannot be guaranteed beforehand' (European Commission, 2005: Art. 2). Furthermore, the accession of Cyprus without unification was a point of political turmoil that later induced the Council to block eight chapters of the negotiations with Turkey in December 2006. These chapters were mostly relevant to trade policy and the upgrading of the bilateral trade relationship, including the CU. ${ }^{4}$ The ambiguity of the accession process

\footnotetext{
${ }^{4}$ The blocked chapters are Free Movement of Goods, Right of Establishment and Freedom to Provide Services, Financial Services, Agriculture and Rural Development,
} 
and reservations from the EU members emerged as key challenges for Turkey's accession negotiations, weakening the mutual trust in relations.

In addition to complexities in the accession process, global economic circumstances also started to change, exposing flaws in the CU. First, the global crisis of 2008 led various advanced economies into turbulence. The crisis-related contraction in demand in eurozone countries influenced the sustainability of European markets for Turkish exporters, who subsequently started to look for alternative markets (see Fig. 12.4).

Second, long before the global crisis, EU trade policy priorities and agenda had started to change in response to shifts in global economy. In October 2006, the Commission published a communication entitled 'Global Europe' (European Commission, 2006) to reinforce the EU's global competitiveness and ensure that the EU got a fair share in emerging economies' markets. The strategy primarily entailed FTAs with major trading partners. It reflected the changing nature of the EU's trade

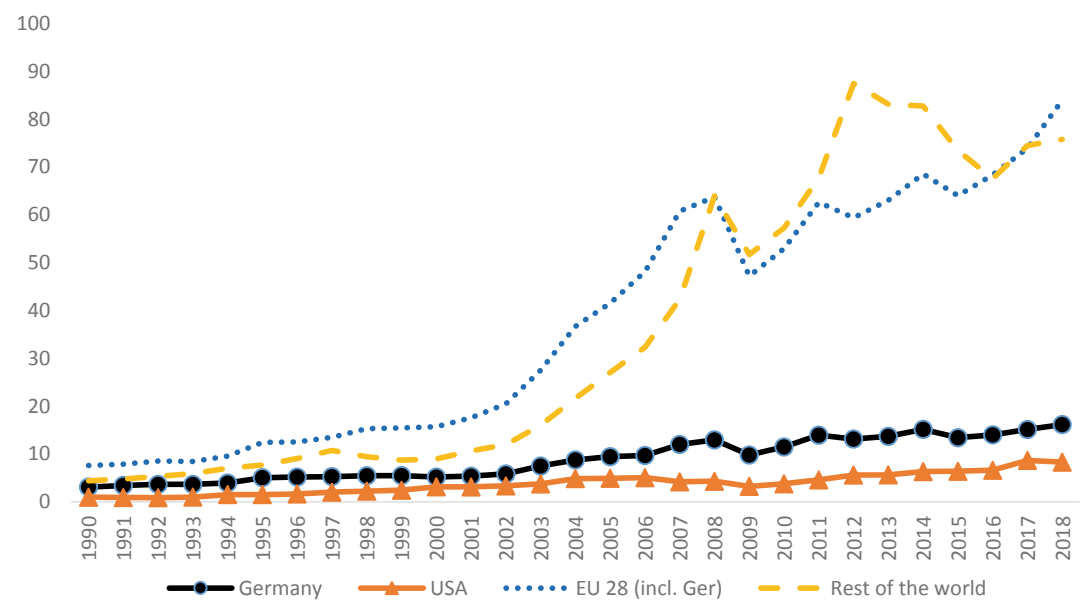

Fig. 12.4 Turkey's total exports to the EU (28), Germany, USA, and the rest of the world (1990-2018) (in billion USD) (Source Updated based on Felbermayr et al. (2016) and OECD STAN Database for Structural Analysis [2020])

Fisheries, Transport Policy, Customs Union and External Relations. For a comprehensive overview of the accession negotiations and the status of individual chapters see also Lippert, Chapter 11. 
policy under new international balance of power and domestic concerns (Young \& Peterson, 2006). The repercussions of the EU's emerging trade policy for Turkey surfaced after the EU started negotiations with major trading partners like India, South Korea, Ukraine, Canada, members of the Association of Southeast Asian Nations, and the Andean countries during 2007-2009.

The EU's proliferation of FTAs signaled an obvious shift from multilateralism to bilateralism, with vast implications for Turkey, as Article 16 of the decision on the $\mathrm{CU}$ forces Turkey to harmonize its preferential trade regime with third countries by signing similar FTAs. Beyond the legal requirement lies an economic necessity. Without these agreements Turkey would face an asymmetrical effect; for example, it would be obliged to open its market to products from the EU's emerging FTA partners with no or very low customs duties, while access to these markets for Turkish exports would not be reciprocated unless the latter agreed to eliminate tariffs to Turkish goods. However, the provisions of the CU did not guarantee Turkey being able to make such deals.

Leading business associations, including TÜSİAD and the Union of Chambers and Commodity Exchanges of Turkey (TOBB), started to raise concerns about this asymmetry and claimed that Turkey's preferences in the EU market would erode under competitive pressure from the EU's FTA partners and decrease its leverage with them (TÜSİAD, 2008; TOBB, 2013). ${ }^{5}$ Criticism peaked when the EU began its Transatlantic Trade and Investment Partnership negotiations with the USA in 2013. Turkey's frustration was voiced not only by business circles but also at higher political levels. Zafer Çağlayan, former Minister of the Economy, publicly announced that unless the asymmetric structure of the CU was removed, a replacement of the CU with an FTA could be considered (Sabah, 2013). While this suggestion implied a step back from the ultimate goal of full membership under the Association Agreement, it mirrored the sensitivities involved.

Ostensibly, in this period the ambiguities of open-ended accession negotiations and changing trade policy preferences as a result of shifting global balances increased pressure on the functioning of the $\mathrm{CU}$ and diminished the EU's anchor role in trade policy. The CU was not

\footnotetext{
${ }^{5}$ For more detailed analysis of criticisms see Akman (2010, 2013).
} 
perfectly negotiated at the beginning and possessed several shortcomings. ${ }^{6}$ However, it should be remembered that the CU was originally designed as a transitional step ahead of Turkey's full membership in the EU, and was never conceived to last for decades. Calls for a reevaluation of the CU and for its possible upgrading were expressed for the first time in 2014 (World Bank, 2014). The report argued that 'the changing global economy is exposing design flaws in the CU' and that 'the CU is increasingly becoming less well equipped to handle the changing dynamics of global trade integration' (World Bank, 2014: i). It proposed far-reaching recommendations for more effective operation of the $\mathrm{CU}$, including the reinforcement of the 'Turkey Clause' in cases of FTA asymmetries, consultation to foster Turkey's alignment with the EU acquis, the widening of the CU's scope to cover trade in services, public procurement, and primary agricultural products, and the formulation of a well-designed dispute-settlement mechanism (World Bank, 2014).

Against this backdrop, the Commission and Turkey announced in May 2015 the launch of preparations for modernizing the CU (European Commission, 2015a). Soon after this joint statement, the Commission published, in August 2015, a roadmap that offered a preliminary assessment of likely economic, social, and political impacts of a modernization (European Commission, 2015b).

\subsubsection{Could a Modernized Customs Union Re-Anchor Turkey to Its EU Route?}

The impact assessment of the Commission was completed with the publication of a report titled 'Study of the EU-Turkey Bilateral Preferential Trade Framework, Including the Customs Union, and an Assessment of its Possible Enhancement' (European Commission, 2016b). It assessed the plausibility of two alternative options to maintaining the status quo: a modernized CU based on an 'enhanced commercial framework' (ECF) that would comprise a continued CU plus an FTA in services and establishment, agriculture, non-tariff barriers (NTBs), and public procurement; or a 'deep and comprehensive FTA' (DCFTA) covering all

\footnotetext{
${ }^{6}$ Earlier studies rightly envisaged that the CU was not yet complete, and institutional weaknesses, together with a loss of belief, threatened its future (Neuwahl, 1999); it was difficult for the $\mathrm{CU}$ to attain the level of integration that the relationship required in order for it to succeed (Peers, 1996).
} 
goods trade, including industrial, agricultural, and fishery products, plus services and establishment, NTBs, and public procurement (European Commission, 2016b). Both options were estimated to bring welfare gains, while economic impact of ECF was higher compared to DCFTA. The findings of the study revealed that the former option creates higher GDP growth for both Turkey and the EU, and that replacing the $\mathrm{CU}$ with an FTA remains an inferior scenario (European Commission, 2016b). Based on this impact assessment the EC asked for the Council's mandate in December 2016 to start negotiations with Turkey on modernizing the $\mathrm{CU}$.

In its July 2017 resolution, the European Parliament (EP) accepted the Commission's proposal to start negotiations but called on the Commission

to include a clause on human rights and fundamental freedoms in the upgraded Customs Union between Turkey and the EU, making human rights and fundamental freedoms a key conditionality. (European Parliament 2017: para. 22)

However, political developments precluded the authorization of the Council. Among the member states with concerns on the update of the CU, Germany revealed the strongest opposition (Özcan, 2017). Echoing this sentiment, the Council stated in its decisions from June 2018 that Turkey was moving away from the EU and that 'no further work towards the modernization of the EU-Turkey Customs Union is foreseen' (Council of the EU, 2018: 13). This sentiment was reiterated in 2019 alongside the statement that accession negotiations had come to a standstill (Council of the EU, 2019). In the 36th meeting of the EU-Turkey Customs Union Joint Committee meeting in July 2019, the EU recalled the previous Council conclusions and recapped 'the need for the full and non-discriminatory implementation of the existing CU' (European Commission, 2019b: 1). However, as Ülgen (2018) argues, taking no action to modernize the $\mathrm{CU}$ is risky considering that trade irritants are cumulative and commitments to implement existing rules are gradually eroding. He underlines that the modernization of the Customs Union would also allow it [the EU] to regain its anchoring role for Turkish policy reform' (Ülgen, 2018: 21).

The trade policy reforms under the EU anchor, largely confined to upgrading the $\mathrm{CU}$, have become a central point of debate 
for influential domestic actors in Turkey. Leading business associations, including TOBB, TÜSİAD, Economic Development Foundation, Turkish Exporters Association, Foreign Economic Relations Board, and Independent Industrialist and Businessmen Association at every opportunity declared their belief in modernizing the $\mathrm{CU}$ and deep regret for the EU's decision to block the opening of negotiations for its upgrading (Duran, 2018).

However, the discourse by Turkish business and political circles lacks credibility for various reasons. First, Turkey's calls to upgrade the $\mathrm{CU}$ is overshadowed by consistent discretionary practices that are not compatible with the existing CU. Turkey has recently introduced highly restrictive customs policies, which primarily take the form of so-called 'additional duties' that apply to an expanded number of industry sectors. Since 2014, the number of additional duties introduced by the Turkish authorities has increased dramatically, directly, or indirectly putting European industrial goods at disadvantage. The stability provided by Turkey's adherence to the CU is eroding as Turkey's regulatory convergence with the EU has been slowing down for years. Compliance with respect to technical barriers to trade in pharmaceuticals, electronics and engineering products, footwear, textiles, and clothing, have become thorny issues. In the field of state aids, Turkey fails to put an effective law into force and consistently delays the notification of subsidy schemes and measures (European Commission, 2016b: 130). Ülgen is correct in noting (2018: 18) that a proper monitoring and implementation of state aid rules in alignment with EU standards could enhance Turkey's business and investment environment.

Second, the impact assessment studies by the World Bank, the EU, and Turkey insistently called attention to welfare gains to be accrued if trade in services and, more notably, agriculture were to be included in the bilateral framework between the EU and Turkey (see World Bank, 2014; European Commission, 2016b; Republic of Turkey Ministry of Economy, 2016). Yet, agricultural liberalization is a complex issue in Turkey, as the Ministry of Agriculture and domestic interests are prone to rent-seeking policies. Despite its willingness to eliminate barriers to market access in services, and its experience in negotiating trade in services in its recent FTAs with South Korea, Singapore, and Malaysia, Turkey has not yet prepared a broad mandate to negotiate service liberalization with the EU. Public procurement is another area considered to be a part of a modernized CU between the EU and Turkey. Nevertheless, large 
public bidding is conducive to economic rent-seeking, especially in infrastructural contracts, and the construction and housing sectors. Turkish legislation has changed several times to allow for ever-increasing exemptions and specific favors, and the practices are largely non-transparent (Ülgen, 2017: 12).

Third, Turkey has not yet come up with any sensible proposal to address the design flaws, which it considers a key driver in its efforts to renew the CU: inter alia, FTA asymmetries, a lack of Turkish participation in regulatory decision-making (in CU-related areas), and an ailing dispute-settlement mechanism. Turkey's negotiation objectives under different scenarios have not been clearly declared yet, nor have they been subject to any proper analysis and policy debate. The impact assessment study the Turkish Ministry of Trade commissioned disclosed that Turkey's overall gain from upgrading would primarily result from an agricultural liberalization. However, the study was not publicized except as a onepage summary (Republic of Turkey Ministry of Economy, 2016), which signals that transparency for public purposes is disregarded (Altay, 2018: 193).

Under these circumstances, Turkey's motivation to upgrade the CU, one of its strongest contractual links with the EU, is weakening, and political announcements do not go beyond paying lip service. Once a major area for Turkey's anchoring to the EU and a stability factor for Turkish business, the CU is currently subject to diminishing returns amid political bickering. It is no longer perceived by Turkish policy circles as a political step toward EU membership, since the course of accession negotiations is not promising. As Ülgen (2017: 18) argues, the failure to modernize the CU may lead 'Turkey to become totally unanchored from Europe'.

\subsection{CONCLUSION}

In this chapter, we outlined how predictable relations with the EU and prospects for membership promoted domestic economic reforms in Turkey. Maintaining a European anchor helped Turkey realize much desired and comprehensive economic and democratic transformation. Macroeconomic policy reforms brought stability and credibility to the Turkish economy in terms of sustained growth, job creation, and inflow of FDI. The EU anchor has given Turkey's transformation stability and confidence, especially during times when it was combined with another 
anchor (such as the IMF, the World Bank, and the WTO). In transforming Turkey's trade policy, the CU played a pivotal role, fostering orderly and smooth trade relations between Turkey and the EU and with third countries.

Turkey's success under the 'double anchoring' of the EU and international institutions in aligning its macroeconomic and trade policies with the EU has waned substantially over time. For Turkey, the EU accession is no longer a prevailing idea amid the complexities of the accession negotiations, changing domestic conditions, and ambiguous signals from the EU. At the same time, the growing discretionary power of the executive under the new presidential system has increased unpredictability in Turkey. Turkey's economy is largely backsliding, with current account and budgetary deficits, rising inflation, and growing external debts.

Trade partnership remains one of the few well-functioning legs of the volatile bilateral dialogue between the EU and Turkey. At the same time, it requires a strong upgrading of the $\mathrm{CU}$ in order to enhance mutual gains for both Turkey and the EU under a revitalized bilateral trading environment. The CU is outdated in its original form and does not reflect the realities of modern trade relations. Its modernization, as evidenced by many economic studies, is essential, but the political climate in Europe and the economic policy approach currently prevailing in Turkey threatens the process. The failure to upgrade the $\mathrm{CU}$ is likely to further diminish Turkey's anchorage to Europe.

Given the doubts about Turkey's full membership prospects and under changing global circumstances-in particular the shift of the economic gravity center toward Asia and China, while advanced economies lost their comparative advantages in setting multilateral rules successive AKP governments began to reassess their global strategies and degraded the role of the EU (Esfahani \& Çeviker-Gürakar, 2013: 375-376). This induced Turkey to liberate itself from strict EU-related conditionality (also from the IMF) once the accession negotiations had lost their attraction. Despite a continued discourse about Turkey's willingness to be involved in the negotiations and to modernize the CU, the policies of the AKP government indicate that Turkish policymakers are no longer interested in tying their hands by adhering to an ambiguous EU anchor. However, Turkey's current political regime is conducive to macroeconomic instability in the absence of external anchors. This leads to a time-inconsistency problem once again, as domestic actors do not consider macroeconomic and trade policies sufficiently predictable. 


\section{REFERENCES}

Acemoğlu, D., \& Üçer, M. (2015, October). The ups and downs of Turkish growth, 2002-2015: Political dynamics, the European Union and the institutional slide (NBER Working Paper No. 21608). https://www.nber.org/sys tem/files/working_papers/w21608/w21608.pdf. Accessed 28 Nov 2020.

Akman, M. S. (2010). The European Union's trade strategy and its reflection on Turkey: An evaluation from the perspective of free trade agreements. Dokuz Eylül Üniversitesi Sosyal Bilimler Enstitüsü Dergisi, 12(2), 17-45.

Akman, M. S. (2012). Turkey in the world trading system and the WTO: Activism under global challenges and the EU process. Afro Eurasian Studies, $1(1), 134-172$.

Akman, M. S. (2013). Dynamics of European Union's trade strategy: Drawing conclusions for relations with Turkey. In B. Akçay \& B. Yilmaz (Eds.), Turkey's accession to the European Union: Political and economic challenges (pp. 129162). Lanham: Lexington.

Alpan, B. (2021). Europeanization and Turkey's EU accession: Three domains, four periods. Chapter 5 , in this volume.

Altay, S. (2018). Towards a privileged partnership: The EU, Turkey and the upgrade of the Customs Union. Insight Turkey, 20(3), 179-198.

Aysan, A. F., \& Hacıhasanoğlu, Y. S. (2007). Investigation into the determinants of Turkish export-boom in the 2000s. The Journal of International Trade and Diplomacy, 1(2), 159-202.

Balkır, C. (2016). Europeanization of trade policy: An asymmetric track. In A. Güney \& A. Tekin (Eds.), The Europeanization of Turkish public policies: A scorecard (pp. 12-29). London: Routledge.

Central Bank of the Republic of Turkey (TCMB). (2019). Balance of payments directorate, foreign direct investments in Turkey.

Council of the European Union. (2001). Council Decision of 8 March 2001 on the principles, priorities, intermediate objectives and conditions in the accession partnership with the Republic of Turkey. 2001/235/EC. Official Journal of the European Communities, L, 85/13-23, 24.3.2001.

Council of the European Union. (2014). 3362nd Council meeting. Press release. 16936/14 (Presse 652). Brussels, 16 December.

Council of the European Union. (2018). Enlargement and stabilisation and association process. Council conclusions. 10555/18. Brussels, 26 June.

Council of the European Union. (2019). Council conclusions on enlargement and stabilisation and association process. Press release. 479/19. Brussels, 18 June.

Duran, A. E. (2018, June 28). AB Türk iş dünyasında hayalkırıklığ Deutsche Welle. https://www.dw.com/tr/ab-t\%C3\%BCrk-i\%C5\%9F-d\%C3\% BCnyas $\% C 4 \% B$ lnda-hayalk\%C4\%B lr\%C4\%Blkl\%C4\%Bl\%C4\%9F\%C4\%Bl-yar att\%C4\%Bl/a-44441017-0. Accessed 16 Jun 2020. 
Esfahani, H. S., \& Çeviker-Gürakar, E. (2013). Fading attraction: Turkey's shifting relationship with the EU. The Quarterly Review of Economics and Finance, 53(4), 364-379.

EC-Turkey Association Council. (1996). Decision No 1/95 of 22 December 1995 on implementing the final phase of the Customs Union. Official Journal of the European Communities, L, 35/1-46, 13.2.1996.

European Commission. (1989). Commission opinion on Turkey's request for accession to the community. SEC(89) 2290 final. Brussels, 20 December.

European Commission. (2005). Negotiating framework. Luxembourg, 3 October. https://ec.europa.eu/neighbourhood-enlargement/sites/near/ files/pdf/turkey/st20002_05_tr_framedoc_en.pdf. Accessed 27 Nov 2020.

European Commission. (2006). Global Europe: Competing in the world: A contribution to the EU's growth and jobs strategy. COM(2006) 567 final. Brussels, 4 October.

European Commission. (2014, October). Turkey 2014 progress report. https:// ec.europa.eu/neighbourhood-enlargement/sites/near/files/pdf/key_doc uments/2014/20141008-turkey-progress-report_en.pdf. Accessed 27 Nov 2020.

European Commission. (2015a). EU and Turkey announce modernisation of Custom Union. http://trade.ec.europa.eu/doclib/press/index.cfm?id=1307. Accessed 16 Jun 2020.

European Commission. (2015b, August). Inception impact assessment: enhancement of EU-Turkey bilateral trade relations and modernisation of the EUTurkey Customs Union. https://ec.europa.eu/smart-regulation/roadmaps/ docs/2015_trade_035_turkey_en.pdf. Accessed 20 Jun 2020.

European Commission. (2016a). Turkey 2016 report. SWD(2016) 366 final. Brussels, 09 November.

European Commission. (2016b). Study of the EU-Turkey bilateral preferential trade framework, including the Customs Union, and an assessment of its possible enhancement: Final report. https://trade.ec.europa.eu/doclib/docs/2017/ january/tradoc_155240.pdf. Accessed 27 Nov 2020.

European Commission. (2018). Turkey 2018 report. SWD(2018) 153 final. Strasbourg, 17 April.

European Commission. (2019a). Turkey 2019 report. SWD(2019) 220 final. Brussels, 29 May.

European Commission. (2019b). 36th Meeting of the EU-Turkey Customs Union Joint Committee. Brussels, 8-9 July 2019. Report. https://trade.ec.europa. eu/doclib/docs/2020/january/tradoc_158587.pdf. Accessed 27 Nov 2020.

European Parliament. (2017). European Parliament resolution of 6 July 2017 on the 2016 Commission Report on Turkey. P8_TA(2017)0306. Strasbourg, 6 July. 
Felbermayr, G., Aichele, R., \& Yalçın, E. (2016). Turkey's EU integration at a crossroads. Gütersloh: Bertelsmann Foundation.

Hoekman, B., \& Togan, S. (Eds.). (2005). Turkey: Economic reform and accession to the European Union. Washington: World Bank.

Icoz, G. (2016). The interconnectedness of the past, the present and the future: Where Turkey-EU relations have been, and where they are heading. Journal of Contemporary European Studies, 24(4), 494-508.

International Monetary Fund. (2020). Direction of trade statistics. http://data. imf.org/DOT. Accessed 2 Mar 2020.

Javorcik, B. S., Lo Turco, A., \& Maggioni, D. (2017). New and improved: Does FDI boost production complexity in host countries? The Economic Journal, 128(614), 2507-2537.

Kabaalioğlu, H. (1998). The Customs Union: A final step before Turkey's accession to the European Union? Marmara Journal of European Studies, 6(1), 113-140.

Kaminsky, B., \& Ng, F. (2007). Turkey's evolving trade integration into panEuropean markets. The Journal of International Trade and Diplomacy, 1(2), 35-103.

Keyman, F., \& Öniş, Z. (2004). Helsinki, Copenhagen and beyond: Challenges to the new Europe and the Turkish state. In M. Uğur (Ed.), Europeanization and the nation state (pp. 173-193). London: Routledge.

Lane, P. (2012). The European sovereign debt crisis. Journal of Economic Perspectives, 26(3), 49-68.

Lippert, B. (2021). Turkey as a special and (almost) dead case of EU enlargement policy. Chapter 11, in this volume.

Müftüler-Baç, M. (2017). Turkey's future with the European Union: An alternative model of differentiated integration. Turkish Studies, 18(3), 416-438.

Neuwahl, N. (1999). The EU-Turkey Customs Union: A balance but no equilibrium. European Foreign Affairs Review, 4(1), 37-62.

O'Brennan, J. (2013). Enlargement fatigue and its impact on the enlargement process in the Western Balkans. In L.-A. Brunet (Ed.), The crisis of EU enlargement (pp. 36-44). IDEAS Special Report SR018, November. https://www.lse.ac.uk/ideas/Assets/Documents/reports/LSEIDEAS-Crisis-of-EU-Enlargement.pdf. Accessed 28 Nov 2020.

OECD (2020). STAN database for structural analysis. Paris: OECD. https:// stats.oecd.org/Index.aspx?DataSetCode=STAN. Accessed 5 May 2020.

Öniş, Z. (2003). Domestic politics, international norms and challenges to the state: Turkey-EU relations in the post-Helsinki era. Turkish Studies, 4(1), 9-34.

Öniş, Z. (2004). Turgut Özal and his economic legacy: Turkish neo-liberalism in critical perspective. Middle Eastern Studies, 40(4), 113-134.

Öniş, Z. (2019). Turkey under the challenge of state capitalism: The political economy of the late AKP era. Southeast European and Black Sea Studies, 19(2), 201-225. 
Öniş, Z., \& Bakır, C. (2007). Turkey’s political economy in the age of financial globalization: The significance of the EU anchor. South European Society of Politics, 12(2), 147-164.

Öniş, Z., \& Şenses, F. (2009). Turkish Economy at a new stage of integration into the global economy: Towards a synthesis and the challenges ahead. In $\mathrm{Z}$. Öniş \& F. Şenses (Eds.), Turkey and the global economy: Neo-liberal restructuring and integration in the post-crisis era (pp. 304-314). London/New York: Routledge.

Özcan, C. (2017, August 31). Merkel conveys Germany's veto on Customs Union update with Turkey to Juncker. Hürriyet Daily News. https://www. hurriyetdailynews.com/merkel-conveys-germanys-veto-on-customs-unionupdate-with-turkey-to-juncker-117422. Accessed 15 Jun 2020.

Pamuk, Ş. (2012). Türkiye'nin 200 yıllık iktisadi taribi (2nd ed.). Istanbul: Türkiye İş Bankası Kültür Yayınları.

Panagiotou, R. (2013). The Greek crisis as a crisis of EU enlargement: How will the Western Balkans be affected? Southeast European and Black Sea Studies, 13(1), 89-104.

Pazarbaşığlu, C. (2005). Accession to the European Union: Potential impacts on the Turkish banking sector. In B. M. Hoekman \& S. Togan (Eds.), Turkey: Economic reform and accession to the European Union (pp. 161-186). Washington: World Bank.

Peers, S. (1996). Living in sin: Legal integration under the EC-Turkey Customs Union. European Journal of International Law, 7(3), 411-430.

Republic of Turkey Ministry of Culture and Tourism. (2020). Annual bulletin: Border statistics, 2015, 2016, 2017. https://yigm.ktb.gov.tr/TR-249709/yil lik-bultenler.html. Accessed 2 Aug 2020.

Republic of Turkey Ministry of Economy. (2016). Gümrük Birliği’nin güncellenmesi etki analizi çalısmasi basın bildirisi. https://ticaret.gov.tr/data/ 5b87239113b8761450el8ee6/Etki\%20Analizi\%20-\%20Bas\%C4\%Bln\%20B ildirisi.pdf. Accessed 2 Aug 2020.

Republic of Turkey Ministry of Treasury and Finance. (2020). Economic indicators 2020. https://en.hmb.gov.tr/public-finance. Accessed 2 Aug 2020.

Sabah (2013, March 26). Gümrük Birliği'nden çıkabiliriz. https://www.sabah. com.tr/ekonomi/2013/03/26/caglayan-gumruk-birliginden-cikabiliriz. Accessed 2 Aug 2020.

Tocci, N. (2005). The Europeanization in Turkey: Trigger or anchor for reform? South European Society \& Politics, 10(1), 73-83.

Togan, S. (2012, March). The EU-Turkey Customs Union: A model for future Euro-Med integration (MEDPRO Technical Report No. 9). http://aei.pitt. edu/59180/1/No_9_Togan_on_EU-Turkey_Customs_Union.pdf. Accessed 28 Nov 2020. 
Togan, S., \& Ersel, H. (2005). Macroeconomic policies for Turkey's accession to the EU. In B. Hoekman \& S. Togan (Eds.), Turkey: Economic reform and accession to the European Union (pp. 3-35). Washington: World Bank.

Türkiye Odalar ve Borsalar Birliği (TOBB). (2013). AB'nin mevcut STA müzakereleri ile Türkiye cezalandirnliyor. https://www.tobb.org.tr/Sayfalar/Detay. php?rid=2310\&lst=MansetListesi. Accessed 30 May 2020.

TÜSİAD. (2008). Gümrük Birliği çerçevesinde AB'nin üçüncü ülkelerle yaptığ STA'larm Avrupa ve Türk iş dünyasina etkileri. TÜSİAD Yayını (T-2008-06467), Istanbul.

TÜSIAD. (2019). Yüksek İstişare Toplantısı konuşması Simone Kaslowski, TÜSİAD Yönetim Kurulu Başkanı, Istanbul, 15 May 2019. https://tusiad. org/tr/basin-bultenleri/item/download/9220_989bb563cd39de4le60233 9110da395e. Accessed 31 Jul 2020.

Uğur, M. (1999). The European Union and Turkey: An anchor/credibility dilemma. Aldershot: Ashgate Publishing.

Uğur, M. (2003). Testing times in EU-Turkey relations: The road to Copenhagen and beyond. Journal of Southern Europe and the Balkans, 5(2), $165-183$.

Ülgen, S. (2017). Trade as Turkey's EU anchor. Carnegie Europe, 13 December. https://carnegieeurope.eu/2017/12/13/trade-as-turkey-seu-anchor-pub-75002. Accessed 27 Nov 2020.

Ülgen, S. (2018). The business case for a Turkey-EU Customs Union 2.0. Istanbul: DEIK.

World Bank. (2014). Evaluation of the EU-Turkey Customs Union. Report No. 85830-TR. https://www.worldbank.org/content/dam/Worldbank/doc ument/eca/turkey/tr-eu-customs-union-eng.pdf. Accessed 28 Nov 2020.

Yilmaz, K. (2011). The EU-Turkey Customs Union fifteen years later: Better, yet not the best alternative. South European Society and Politics, 16(2), 235-249.

Young, A., \& Peterson, J. (2006). The EU and the new trade politics. Journal of European Public Policy, 13(6), 795-814.

Mehmet Sait Akman is associate professor of European integration and director of the G20 Studies Center at the Economic Policy Research Foundation of Turkey (TEPAV), Ankara. He is adjunct professor of international trade at TOBB University of Economics and Technology. Akman holds a Ph.D. degree in EU Economics from Marmara University, Istanbul, and an LL.M degree from London School of Economics (LSE). He has been a visiting researcher at the European University Institute, Florence; at LSE, London, and at CIGI, Canada. $\mathrm{He}$ is the co-chair of T20 Trade and Investment Task Force (in 2020). 
Semih Emre Cekin is assistant professor at the Department of Economics, Turkish-German University (TDU), Istanbul. Çekin holds a Ph.D. in Economics from Texas Tech University and a B.Sc in Economics and Management from the University of Tübingen. Before joining the TDU, he worked as a faculty member at the Governors State University in Illinois, USA.

Open Access This chapter is licensed under the terms of the Creative Commons Attribution 4.0 International License (http://creativecommons.org/licenses/ by $/ 4.0 /)$, which permits use, sharing, adaptation, distribution and reproduction in any medium or format, as long as you give appropriate credit to the original author(s) and the source, provide a link to the Creative Commons license and indicate if changes were made.

The images or other third party material in this chapter are included in the chapter's Creative Commons license, unless indicated otherwise in a credit line to the material. If material is not included in the chapter's Creative Commons license and your intended use is not permitted by statutory regulation or exceeds the permitted use, you will need to obtain permission directly from the copyright holder.

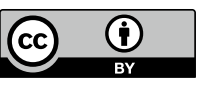

